\title{
Title: Effectiveness of the Covid-19 vaccines in preventing infection in dental practitioners - results of a cross-sectional 'questionnaire-based' survey
}

\author{
Authors: \\ 1. Dr. Sanjeev Kumar* MDS, FDSRCPS(Glasgow), FIBOMS \\ Professor \& Head, Oral \& Maxillofacial Surgery \\ Faculty of Dental Sciences, SGT University, Gurugram (INDIA)
}

2. Dr. Susmita Saxena MDS

Director Professor, Oral \& Maxillofacial Pathology

ESIC Dental College \& Hospital, Rohini, New Delhi (INDIA)

3. Dr. Mansi Atri MDS

Associate Professor, Public Health Dentistry

ESIC Dental College \& Hospital, Rohini, New Delhi (INDIA)

4. Sunil Kumar Chamola

Assistant Professor Cum Statistician, Community Medicine

Faculty of Medicine \& Health Sciences, SGT University, Gurugram (INDIA)

\begin{abstract}
:
India started its vaccination program at the beginning of 2021, the main beneficiaries being health workers and frontline workers including police, paramilitary forces, sanitation workers, and disaster management volunteers in the first phase. By the time, the second wave of Covid-19 impacted India, approximately 14 million healthcare and frontline workers, including dentists had been vaccinated.

Aim: To study the effectiveness of vaccination on a subset of high-risk healthcare workers i.e. dentists in preventing Covid-19 during the second wave of the pandemic.

Study design: A questionnaire based pan-India online survey was carried out to record the Covid-related experiences of dentists prior to and after vaccination.

Result: The sample size for this survey was 4493 respondents from across India. During the second wave, $9.18 \%(\mathrm{n}=364)$ respondents became positive in spite of the vaccine, while $14.69 \%(\mathrm{n}=78)$ became positive in the unvaccinated group. A chi-square test of independence was performed to examine the relation between vaccination and the Covid positivity rate in all age groups. The relation between these variables was highly significant, $[X 2(1, N=4493)=$ 15.9809, $p=.000064]$.

Conclusion: Our pan-India online survey inferred that vaccination has a definitive role to play in reducing the positivity rate amongst dentists during the second wave of the pandemic across all age groups.
\end{abstract}


medRxiv preprint doi: https://doi.org/10.1101/2021.05.28.21257967; this version posted June 3, 2021. The copyright holder for this preprint (which was not certified by peer review) is the author/funder, who has granted medRxiv a license to display the preprint in perpetuity. It is made available under a CC-BY-NC-ND 4.0 International license .

\section{Introduction}

In early January 2021, the Drug Controller General of India (DCGI) approved two vaccines for clinical use, the Oxford-AstraZeneca vaccine, which is manufactured by the Serum Institute of India (SII) under the trade name "Covishield" and Bharat Biotech's "Covaxin".

On 16 January 2021, India began its massive vaccination program, targeting health workers and frontline workers including police, paramilitary forces, sanitation workers, and disaster management volunteers in the first phase. By 1 March 2021, 14 million healthcare and frontline workers, including dentists had been vaccinated. ${ }^{1}$ The next phase of the vaccine rollout covered all residents over the age of 60 , residents between the ages of 45 and 60 with one or more qualifying comorbidities, and any health-care or frontline worker that did not receive a dose during phase $1 .{ }^{2}$

India is currently experiencing the onslaught of an aggressive second wave of Covid-19 infection which began around 11 February 2021 in Maharashtra. The situation progressively worsened in April 2021, ending the month by repeatedly setting new global records for daily cases. Two strains; the highly contagious U.K. variant (B.1.1.7) and the Indian variant( B.1.617) are believed to be causing this rapid rise in cases during the second wave. ${ }^{3}$ The overall nationwide test positivity rate was above $20 \%$ in April and the second wave was expected to peak around mid-May with infections exceeding 0.4 million/day. ${ }^{4}$ Till date, India has crossed 288,232 reported deaths ${ }^{5}$, of which more than 48,000 people have lost their lives to the disease in April 2021 alone. $^{3}$

Dentistry is at the top of all professions most susceptible to contract Covid-19 because of the physical proximity to their patients. ${ }^{6}$ A spate of deaths due to Covid-19 within the dental community during the second wave has created anxiety among practitioners that the vaccines may not be as protective against the new mutant strains of SARS-CoV-2. No study has yet proven that the currently available vaccines in India are protective against the new variants in high-risk professions such as dentistry.

This cross-sectional questionnaire based pan-India online survey was carried out to record the Covid-related experiences of dentists prior to and after vaccination. The primary aim of the study was to assess whether vaccination has helped to reduce the positivity rate amongst dentists during the second wave.

The secondary objectives were to assess whether:

1. the vaccine protects against infection across all age groups?

2. the vaccine leads to less severe symptoms in vaccinated persons?

3. a single dose of vaccine is as effective as the two dose regime in preventing infection?

4. two dose regime of vaccine help to prevent more severe symptoms in persons compared to those who received only a single dose of vaccine?

5. vaccine is effective in preventing Covid 19 in persons with comorbidities?

6. Covishield is more effective than Covaxin in preventing infection or vice versa?

\section{Methodology}

A cross-sectional survey was conducted from $29^{\text {th }}$ April to $2^{\text {nd }}$ May 2021, 11 weeks after the second wave of Covid-19 hit India. The data was collected online via a simple questionnaire of 15 items created on Google forms (annexure). Care was taken not to collect any information which would disclose the respondents' identity and participation was completely voluntary. 
medRxiv preprint doi: https://doi.org/10.1101/2021.05.28.21257967; this version posted June 3, 2021. The copyright holder for this preprint (which was not certified by peer review) is the author/funder, who has granted medRxiv a license to display the preprint in perpetuity. It is made available under a CC-BY-NC-ND 4.0 International license .

The link for the Google Form was shared electronically in various dentistry related groups on Whatsapp, a freeware, cross-platform centralized messaging and voice-over-IP (VoIP) service owned by Facebook, Inc. The purpose for which the data was being collected was clearly specified in the accompanying message and the willingness to participate in the survey was considered as implied consent.

All responses received in the stipulated time-period were converted online to a Google spreadsheet for data analysis.

The data was analyzed online on https:/www.socscistatistics.com/tests/. The output of the calculators and tools featured on this website has been audited for accuracy against the output produced by a number of established statistics packages, including SPSS and Minitab. ${ }^{1}$ The test applied was Chi square test of independence and the significance level was set at .05. The results were significant when $p<.05$.

\section{Results}

From $29^{\text {th }}$ April to $2^{\text {nd }}$ May 2021, a total of 4493 responses were collected online. Out of 28 States and 8 Union Territories of India, responses were received from 26 states and 7 Union Territories (Table 1). No dentists responded from the states of Manipur and Nagaland and the UT of Ladakh. The age distribution of the respondents is shown in Graph $1.74 .43 \%(n=3344)$ respondents were below the age of 45 years, while $25.57 \%(n=1149)$ were above 45 years. $51.56 \%(n=2317)$ of the respondents were females while $47.96 \%(n=2155)$ were males. $21(0.46 \%)$ respondents did not reveal their sex.

$81.08 \%(n=3643)$ were healthy individuals while $18.92 \%(n=850)$ had co-morbidities. Among those above 45 years of age, $36.98 \%(n=425)$ had associated co-morbidities, while $12.70 \%(n=425)$ among those below 45 years of age reported associated co-morbidities. This difference was statistically significant $[X 2(1, N=4493)=328.6389, p=.00001]$.

In the age group of the respondents above 45 years having co-morbidities, $39.76 \%(\mathrm{n}=169)$ were diabetic, while in the age group below 45 years having comorbidities, $24.24 \%(n=103)$ were diabetic. This difference was also statistically significant $[X 2(1, N=850)=23.551$, $p=.00001] .($ Table 2)

During the vaccination drive, of 4493 respondents, $88.18 \%(n=3962)$ received at least one dose of either Covishield or Covaxin while $11.81 \%(\mathrm{n}=531)$ did not receive vaccination. While $85.59 \%(n=2862)$ of the respondents below the age of 45 years were vaccinated, $95.73 \%(n=1100)$ above the age of 45 years were vaccinated. The difference in vaccination between the two age groups was statistically significant.(Table 3).

During the second wave, $9.18 \%(\mathrm{n}=364)$ respondents became positive in spite of the vaccine, while $14.69 \%(n=78)$ became positive in the unvaccinated group. A chi-square test of independence was performed to examine the relation between vaccination and the Covid positivity rate in all age groups. The relation between these variables was highly significant, $[X 2(1, N=4493)=15.9809$, $p=.000064]$. Age-related association between vaccination status and positivity rate was also studied. The relation between these variables for ages below 45 years was significant $[X 2(1, N=$ $3344)=14.7204, p=.000125]$, but for ages above 45 years $[X 2(1, N=1149)=0.1708, p=.679375]$ it was not significant (Table 4 ). 
medRxiv preprint doi: https://doi.org/10.1101/2021.05.28.21257967; this version posted June 3, 2021. The copyright holder for this preprint (which was not certified by peer review) is the author/funder, who has granted medRxiv a license to display the preprint in perpetuity. It is made available under a CC-BY-NC-ND 4.0 International license .

At the time of the survey, $39.35 \%(n=1559)$ respondents were yet to complete their scheduled second vaccination while $60.25 \%(\mathrm{n}=2387)$ had received both doses of the vaccine. 16 respondents did not mention the status of their vaccination. The data showed that $58.94 \%(n=1681)$ below 45 years received both doses of the vaccine, as did $64.53 \%(n=706)$ above 45 years before the second wave hit India. This difference was significant statistically. (Table 5)

$8.21 \%(n=128)$ respondents who had received just one dose, turned positive while $9.88 \%(n=236)$ respondents who received both doses, turned positive. This difference was however not statistically significant across all age groups $[X 2(1, N=3946)=3.17, p=.075212]$. The positivity rate in respondents below 45 as well as in respondents above 45 years of age too did not differ significantly in those receiving single or both $\operatorname{doses}[X 2(1, N=2852)=3.7205, p=.053748],[X 2$ $(1, N=1094)=0.0732, p=.786696]$. (Table 6).

In the unvaccinated group 71 of the 78 positive respondents described their symptoms. $78.87 \%$ $(\mathrm{n}=56)$ had mild and $21.13 \%(\mathrm{n}=15)$ had moderate symptoms. In the vaccinated group, 348 of the 364 positive respondents their symptoms. $82.18 \%(n=288)$ described them as mild, $16.38 \%(n=57)$ as moderate and $1.44 . \%(n=5)$ as severe. Statistically, the difference between symptoms in vaccinated and non-vaccinated respondents was not significant $[X 2(1, N=419)=0.4309$, $p=.511553] .79 .68 \%(\mathrm{n}=102)$ of the respondents who had only one dose of vaccination showed mild symptoms compared to $83.64 \%(n=184)$ who had both doses. Statistically, the difference between symptoms in those who received a single dose, or two doses was not significant $[X 2$ ( 1 , $N=348)=0.8618, p=.35324]$ (Table 7).

In respondents with comorbidities, $8.4 \%(\mathrm{n}=72)$ reported positive for Covid-19 compared to $10.16 \%(\mathrm{n}=370)$ healthy respondents. This difference was not statistically significant $[X 2(1, N=$ $4493)=2.2084, p=.137259] .9 .5 \%(\mathrm{n}=303)$ of vaccinated respondents without comorbidities had Covid-19 compared to $7.9 \%(\mathrm{n}=61)$ of vaccinated respondents with comorbidities. This difference was also not statistically significant $[X 2(1, N=3962)=1.90, p=.168103] 7.90 \%(\mathrm{n}=61)$ vaccinated respondents with comorbidities tested positive compared to $14.10 \%(n=11)$ who did not receive the vaccine. This difference too was not statistically significant $[X 2(1, N=850)=3.5135, p=.06087]$ at $\mathrm{p}<.05$ (Table 8$)$.

Diabetic patients were analyzed separately because of their susceptibility to Covid-19. $32 \%(n=272)$ respondents with comorbidities were diabetic. Of these $94.85 \%(n=258)$ had received at least one dose of the vaccine. $7.36 \%(n=19)$ of these vaccinated respondents were infected with the virus. The chi square test for independence was not significant $[X 2(1, N=272)=3.5333$, $p=.060146]$ (Table 9).

Among the total sample of 4493 respondents, $3962(88.18 \%)$ had received at least one dose of vaccine. 3663(92.45\%) had received the Covishield vaccine from Astra Zeneca, while 299(7.55\%) had received Covaxin from Bharat Biotech. 8.36\% respondents who received the Covaxin and $9.25 \%$ respondents who received Covishield turned positive during the second wave. Statistically, the difference between the two vaccines in their protective capability was not significant $[X 2(1, N$ = 3962) $=0.26, p=.607033$ ] (Table 10).

\section{Discussion}

With a population of 1.38 billion, in the initial phase of the COVID-19 vaccination programme, India aimed at vaccinating 300 million people by August 2021, including 30 million health workers and frontline workers (eg, police, soldiers), and 270 million elderly people (ie, aged over 50 years) 
medRxiv preprint doi: https://doi.org/10.1101/2021.05.28.21257967; this version posted June 3, 2021. The copyright holder for this preprint

(which was not certified by peer review) is the author/funder, who has granted medRxiv a license to display the preprint in perpetuity. It is made available under a CC-BY-NC-ND 4.0 International license .

and people with co-morbidities. India's strong domestic vaccine sector has enabled the country to launch one of the largest and fastest COVID-19 vaccination campaigns in the world. ${ }^{7}$

Two vaccines were launched simultaneously for clinical use in India: Covishield, developed by the Oxford-AstraZeneca and manufactured by the Serum Institute of India (SII) is prepared using the viral vector platform which utilizes a modified chimpanzee adenovirus - ChAdOx1 to carry the COVID-19 spike protein into the cells of humans and launch an immune response. ${ }^{8}$ The indigenous Covaxin has been developed by Hyderabad-based Bharat Biotech International Ltd in association with the Indian Council of Medical Research (ICMR) and the National Institute of Virology (NIV). It is developed by utilizing Whole-Virion Inactivated Vero Cell-derived technology. ${ }^{8}$

There is growing concern that emerging coronavirus variants may evade aspects of the immune responses stimulated by some vaccines. For example, in an analysis of about 2,000 people in South Africa, the AstraZeneca vaccine did not protect against mild or moderate COVID-19 due to the B.1.351 variant. ${ }^{9}$ The current wave of Covid-19 in India was believed to be caused by several new variants especially U.K. variant (B.1.1.7) and the Indian variants ( B.1.617 and B.1.618). By May 2021, B.1.617 variant has become the dominant strain across India and has spread to about 40 nations, including the United Kingdom, Fiji and Singapore prompting the World Health Organization to designate it as a 'variant of concern'. Researchers from India have reported that some health-care workers in Delhi, vaccinated with Covishield had become reinfected with B.1.617. Reduction in the effectiveness of neutralizing antibodies generated by Covaxin against this variant, albeit small, have also been reported..$^{10}$

Against this background, the present study was conducted to determine the effects of vaccination on positivity rate and severity of symptoms among Indian dentists during the second wave of Covid-19. Dentists were selected as the study sample as they are a high-risk sub-group of healthcare workers, in whom exposure to SARS-CoV-2 virus is likely to be more than in the general population. It is assumed that positive effects of the vaccine in this sub-group, if any, would be applicable to the whole population. The cue to analyze the data in two age groups separately i.e. above and below the age of 45 was taken from the Indian government's vaccination strategy based on susceptibility to infection. In this study, almost $2 / 3^{\text {rd }}$ respondents were below the age of 45 indicative of the young dental workforce of India. Expectedly, the older age group had a significantly greater proportion of respondents with comorbidities including diabetes.

In our sample, $88.18 \%$ dentists participated in the government's vaccination drive indicating a highly informed sub-group of healthcare workers. With over $95 \%$ compliance, the older age group of dentists showed exceptional enthusiasm in getting themselves vaccinated. In contrast, according to media reports less than $50 \%$ of frontline health workers had got vaccinated by $19^{\text {th }}$ April $2021 .^{11}$

As a clear indication of efficacy of COVID-19 vaccines, our data indicates that non-vaccinated individuals across all age groups were more likely to get infected with the virus. The result corroborate the findings of similar studies done in other countries. ${ }^{12,13}$ Interestingly, according to our analysis, these vaccines seem to be more protective in the younger age group rather than in older individuals. The reason for this discrepancy may be a result of sampling error.

Several studies show that a high proportion of elderly individuals have suboptimal neutralising antibody responses following first dose vaccination with mRNA-based vaccines Pfizer-BioNTech and Moderna vaccine. ${ }^{14,15,16,17}$ Our data revealed that a single dose of the two vaccines available 
medRxiv preprint doi: https://doi.org/10.1101/2021.05.28.21257967; this version posted June 3, 2021. The copyright holder for this preprint (which was not certified by peer review) is the author/funder, who has granted medRxiv a license to display the preprint in perpetuity. It is made available under a CC-BY-NC-ND 4.0 International license .

in India was as effective as two doses of vaccines in preventing infection in all age groups, including in the older age group of above 45 years. Since Covishield and Covaxin are both nonmRNA based vaccines, it is possible that the difference in formulation may be responsible for the increased immune response seen by even a single dose.

It has been reported that the COVID-19 vaccines help reduce severity of infection and need for hospitalization. ${ }^{18}$ This claim was refuted by our study, as no significant difference was observed in the severity of symptoms in vaccinated and non-vaccinated group or even in those receiving either a single or both doses of vaccine.

The novel coronavirus disease (COVID-19) tends to portend a poor prognosis in patients with diabetes mellitus (DM). Primary prevention with timely vaccination remains the mainstay for mitigating the risks associated with COVID-19 in patients with DM. ${ }^{19}$ In our sample, individuals with comorbidities did not show an increased susceptibility to infection compared to those without any comorbidities. Our analysis indicates that vaccines appear to be as effective in reducing the incidence of Covid-19 in the population with comorbidities as in healthy individuals. However, vaccines do not seem to reduce the positivity rate within this compromised group. Specifically, in respondents suffering from diabetes mellitus, the positivity rate did not change significantly with vaccination.

On-going research has shown that both Covaxin and Covishield are likely to be protective to limit the severity and mortality of the disease in the vaccinated individuals, in-spite of reduction in the neutralizing titer against B.1.617.1 variant. ${ }^{20,21}$ Our cross-sectional data demonstrated that currently there is little to choose between Covaxin and Covishield, both having similar capability to prevent Covid-19.

\section{Conclusion}

Our pan-India online survey inferred that vaccination has a definitive role to play in reducing the positivity rate amongst dentists during the second wave across all age groups. In addition, a single of vaccine seems to be as effective as two doses of vaccine in preventing infection with SARSCoV-2 virus. However, the vaccines did not reduce the severity of infection in the sample studied. The vaccines seem to be equally effective against infection in persons with co-morbidities as in healthy individuals. The two vaccines available currently in India, Covishield and Covaxin, are equally effective and there is no relation between the type of vaccine administered and the positivity rate among vaccinated persons. 
medRxiv preprint doi: https://doi.org/10.1101/2021.05.28.21257967; this version posted June 3, 2021. The copyright holder for this preprint (which was not certified by peer review) is the author/funder, who has granted medRxiv a license to display the preprint in perpetuity. It is made available under a CC-BY-NC-ND 4.0 International license .

\section{References}

1. Social Science Statistics. (2021). Retrieved 28 May 2021, from https:/www.socscistatistics.com/

2. Wikipedia contributors. COVID-19 vaccination in India. Wikipedia, The Free Encyclopedia. May 18, 2021, 16:22 UTC. Available at: https://en.wikipedia.org/w/index.php?title=COVID19 vaccination_in_India\&oldid=1023834067. Accessed May 19, 2021.

3. Roy Chowdhury S. India accounts for 1 in 3 new Covid cases being recorded. Here is its second wave in 5 charts.CNBC. May 3, 2021,11:22 AM EDT. Available at:https://www.cnbc.com/2021/05/03/india-covid-crisis-charts-show-the-severity-of-the-secondwave.html. Accessed on May 7, 2021

4. Ranjan R, Sharma A, Verma M.K. Characterization of the Second Wave of COVID-19 in India. medRxiv 2021.04.17.21255665; doi: https://doi.org/10.1101/2021.04.17.21255665.

5. Covid19.org (2021).Available at: https://www.covid19india.org/. Accessed on May 19, 2021

6. Alberta Federation of Labour. As Albertans return to work, who is at the highest risk of exposure to the novel coronavirus? May 21,2020.Available at https://www.afl.org/as albertans return to work who is at the highest risk of exposure to $t$ he_novel_coronavirus. Accessed on May 7, 2021

7. Bagcchi S. The world's largest COVID-19 vaccination campaign. The Lancet Infectious Diseases 2021: 21(3):323 Available at: doi: https://doi.org/10.1016/S1473-3099(21)00081-5

8. Budania R (Reviewer). "Covaxin vs Covishield - A Detailed Comparison." PharmEasy Blog, 14 May 2021, pharmeasy.in/blog/covaxin-vs-covishield-a-detailed-comparison/.

9. Ledford H. Why covid vaccines are so difficult to compare. Nature 4 March 2021; 591:17

10. Vaidyanathan G. Coronavirus variants are spreading in India — what scientists know so far. Nature 20 May 2021;593:321

11. TNN(2021, April 19). Only $37 \%$ of 3 crore health, frontline workers fully vaccinated. The Times of India. Retrieved from https://timesofindia.indiatimes.com/india/only-37-of-3-crore-healthfrontline-workers-fully-vaccinated/articleshowprint/82135322.cms

12. Bouton T.C, Lodi S, Turcinovic J, Weber S.E, Quinn E, Korn C, Steiner J, Schechter-Perkins E.M, Duffy E, Ragan E.J, Taylor B.P, Schaeffer B, Miller N, Davidoff R, Hanage W.P, Connor J, Pierre C, Jacobson K.R. COVID-19 vaccine impact on rates of SARS-CoV-2 cases and post vaccination strain sequences among healthcare workers at an urban academic medical center: a prospective cohort study.medRxiv 2021.03.30.21254655; doi: https://doi.org/10.1101/2021.03.30.21254655

13. Glampson B, Brittain J, Kaura A, Mulla A, Mercuri L, Brett S, Aylin P, Sandall T, Goodman I, Redhead J, Saravanakumar K, Mayer E.K. North West London Covid-19 Vaccination Programme: Real-world evidence for Vaccine uptake and effectiveness. medRxiv 2021.04.08.21254580; doi: https://doi.org/10.1101/2021.04.08.21254580

14. Collier D.A, Ferreira I.A.T.M, Datir R, Meng B, Bergamaschi L, The CITIID-NIHR BioResource COVID-19 Collaboration, Elmer A, Kingston N, Graves B, Smith K.G.C, Bradley J.R, Lyons P.A, 
medRxiv preprint doi: https://doi.org/10.1101/2021.05.28.21257967; this version posted June 3, 2021. The copyright holder for this preprint (which was not certified by peer review) is the author/funder, who has granted medRxiv a license to display the preprint in perpetuity. It is made available under a CC-BY-NC-ND 4.0 International license .

Ceron-Gutierrez L, Barcenas-Morales G, Doffinger R, Wills M, Gupta R.K. Age-related heterogeneity in neutralising antibody responses to SARS-CoV-2 following BNT162b2 vaccination. medRxiv 2021.02.03.21251054; doi: https://doi.org/10.1101/2021.02.03.21251054

15. Walsh EE, Frenck RW Jr, Falsey AR, Kitchin N, Absalon J, Gurtman A, Lockhart S, Neuzil K, Mulligan MJ, Bailey R, Swanson KA, Li P, Koury K, Kalina W, Cooper D, Fontes-Garfias C, Shi PY, Türeci Ö, Tompkins KR, Lyke KE, Raabe V, Dormitzer PR, Jansen KU, Şahin U, Gruber WC. Safety and Immunogenicity of Two RNA-Based Covid-19 Vaccine Candidates. N Engl J Med. 2020 Dec 17;383(25):2439-2450. doi: 10.1056/NEJMoa2027906. Epub 2020 Oct 14. PMID: 33053279; PMCID: PMC7583697.

16. Anderson EJ, Rouphael NG, Widge AT, Jackson LA, Roberts PC, Makhene M, Chappell JD, Denison MR, Stevens LJ, Pruijssers AJ, McDermott AB, Flach B, Lin BC, Doria-Rose NA, O'Dell S, Schmidt SD, Corbett KS, Swanson PA 2nd, Padilla M, Neuzil KM, Bennett H, Leav B, Makowski M, Albert J, Cross K, Edara VV, Floyd K, Suthar MS, Martinez DR, Baric R, Buchanan W, Luke CJ, Phadke VK, Rostad CA, Ledgerwood JE, Graham BS, Beigel JH; mRNA-1273 Study Group. Safety and Immunogenicity of SARS-CoV-2 mRNA-1273 Vaccine in Older Adults. N Eng1 J Med. 2020 Dec 17;383(25):2427-2438. doi: 10.1056/NEJMoa2028436. Epub 2020 Sep 29. PMID: 32991794; PMCID: PMC7556339.

17. Müller, L. et al. Age-dependent immune response to the Biontech/Pfizer BNT162b2 COVID-19 vaccination. medRxiv, 2021.2003.2003.21251066, doi:10.1101/2021.03.03.21251066

18. Lopez Bernal J, Andrews N, Gower C, Robertson C, Stowe J, Tessier E et al. Effectiveness of the Pfizer-BioNTech and Oxford-AstraZeneca vaccines on covid-19 related symptoms, hospital admissions, and mortality in older adults in England: test negative case-control study BMJ 2021; 373 :n1088 doi:10.1136/bmj.n1088

19. Pal R, Bhadada SK, Misra A. COVID-19 vaccination in patients with diabetes mellitus: Current concepts, uncertainties and challenges. Diabetes Metab Syndr. 2021;15(2):505-508. doi:10.1016/j.dsx.2021.02.026

20. Yadav P.D, Sapkal G.N, Abraham P, Ella R, Deshpande G, Patil D.Y, Nyayanit D.A, Gupta N, Sahay R.R, Shete A.M, Panda S, Bhargava B, Mohan V.K. Neutralization of variant under investigation B.1.617 with sera of BBV152 vaccinees. bioRxiv 2021.04.23.441101; doi: https://doi.org/10.1101/2021.04.23.441101

21. Yadav P.D, Sapkal G.N, Abraham P, Deshpande G, Nyayanit D.A, Patil D.Y, Nivedita Gupta, Gupta N, Sahay R.R, Shete A.M, Kumar S, Panda S, Bhargava B. Neutralization potential of Covishield vaccinated individuals sera against B.1.617.1.bioRxiv 2021.05.12.443645; doi: https://doi.org/10.1101/2021.05.12.443645 
medRxiv preprint doi: https://doi.org/10.1101/2021.05.28.21257967; this version posted June 3, 2021. The copyright holder for this preprint (which was not certified by peer review) is the author/funder, who has granted medRxiv a license to display the preprint in perpetuity. It is made available under a CC-BY-NC-ND 4.0 International license .

\begin{tabular}{|c|c|c|}
\hline 7 & Maharashtra & 1495 \\
\hline 2 & Karnataka & 587 \\
\hline 3 & Gujarat & 367 \\
\hline 4 & Uttar Pradesh & 322 \\
\hline 5 & Andhra Pradesh & 265 \\
\hline 6 & Telangana & 215 \\
\hline 7 & Delhi & 200 \\
\hline 8 & West Bengal & 149 \\
\hline 9 & Punjab & 135 \\
\hline 10 & Haryana & 97 \\
\hline 11 & Tamil Nadu & 95 \\
\hline 12 & Kerala & 93 \\
\hline 13 & Tripura & 89 \\
\hline 14 & Rajasthan & 82 \\
\hline 15 & Madhya Pradesh & 49 \\
\hline 16 & Jharkhand & 47 \\
\hline 17 & Chandigarh & 41 \\
\hline 18 & Chhattisgarh & 33 \\
\hline 19 & Bihar & 22 \\
\hline 20 & Himachal Pradesh & 19 \\
\hline 21 & Uttarakhand & 16 \\
\hline 22 & Sikkim & 14 \\
\hline 23 & Jammu and Kashmir & 13 \\
\hline 24 & Puducherry & 10 \\
\hline 25 & Odisha & 10 \\
\hline 26 & Goa & 9 \\
\hline 27 & Assam & 8 \\
\hline 28 & Meghalaya & 4 \\
\hline 29 & Arunachal Pradesh & 2 \\
\hline 30 & Lakshadweep & 2 \\
\hline 31 & Mizoram & 1 \\
\hline 32 & Andaman and Nicobar Islands & 1 \\
\hline 33 & Dadra and Naqar Haveli & 1 \\
\hline
\end{tabular}

Table 1 : State-wise distribution of respondents

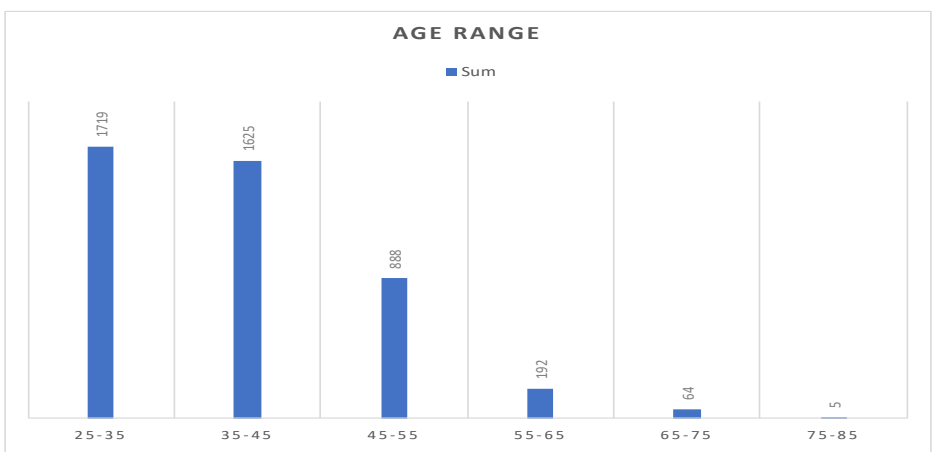

Graph 1: Age-wise distribution of respondents 
medRxiv preprint doi: https://doi.org/10.1101/2021.05.28.21257967; this version posted June 3, 2021. The copyright holder for this preprint (which was not certified by peer review) is the author/funder, who has granted medRxiv a license to display the preprint in perpetuity. It is made available under a CC-BY-NC-ND 4.0 International license .

\begin{tabular}{|c|c|c|c|}
\hline & Co-morbidities & No Co-morbidities & Marginal Row Totals \\
\hline Below 45 & $425(632.63)[68.14]$ & 2919 (2711.37) [15.9] & 3344 \\
\hline Over 45 & 425 (217.37) [198.32] & $724(931.63)$ [46.27] & 1149 \\
\hline Marginal Column Totals & 850 & 3643 & 4493 (Grand Total) \\
\hline \multicolumn{4}{|c|}{ The chi-square statistic is 328.6389. The $p$-value is $<0.00001$. Significant at $p<.05$. } \\
\hline & Diabetes & Other comor & Marginal 1 \\
\hline Below 45 & $103 \quad(136) \quad[8.01]$ & $322(289) \quad[3.77]$ & 425 \\
\hline Above 45 & $169 \quad(136)[8.01]$ & $256 \quad(289) \quad[3.77]$ & 425 \\
\hline Marginal Column Totals & 272 & 578 & 850 (Grand Total) \\
\hline
\end{tabular}

\begin{tabular}{|l|ll|ll|l|}
\hline & \multicolumn{2}{|l|}{ Vaccinated } & Not Vaccinated & Marginal Row Totals \\
\hline Below 45 & $2862(2948.79)$ & {$[2.55]$} & $482(395.21)$ & {$[19.06]$} & 3344 \\
\hline Over 45 & $1100(1013.21)$ & {$[7.43]$} & $49(135.79)$ & {$[55.47]$} & 1149 \\
\hline Marginal Column Totals & 3962 & 531 & $4493 \quad$ (Grand Total) \\
\hline \multicolumn{2}{|l|}{} \\
\hline
\end{tabular}

Table 3: Age-related difference in vaccinated vs non-vaccinated respondents

\begin{tabular}{|c|c|c|c|}
\hline All ages & Covid +ve & Covid-ve & Marginal Row Totals \\
\hline vaccinated & $364(389.76)[1.7]$ & $3598 \quad(3572.24) \quad[0.19]$ & 3962 \\
\hline nonvaccinated & $78 \quad(52.24) \quad[12.71]$ & 453 (478.76) $[1.39]$ & 531 \\
\hline Marginal Column Totals & 442 & 4051 & 4493 (Grand Total) \\
\hline \multicolumn{4}{|c|}{ The chi-square statistic is 15.9809 . The $p$-value is .000064 . Significant at $p<.05$. } \\
\hline & Covid +ve & Covid-ve & Marginal Row Totals \\
\hline$<45$ vaccinated & $279 \quad(302.97) \quad[1.9]$ & $2583 \quad(2559.03) \quad[0.22]$ & 2862 \\
\hline$<45$ nonvaccinated & $75(51.03) \quad[11.26]$ & $407 \quad(430.97)$ [1.33] & 482 \\
\hline Marginal Column Totals & 354 & 2990 & 3344 (Grand Total) \\
\hline \multicolumn{4}{|c|}{ The chi-square statistic is 14.7204 . The $p$-value is .000125 . Significant at $p<.05$. } \\
\hline & Covid +ve & Covid-ve & Marginal Row Totals \\
\hline$>45$ vaccinated & $85(84.25) \quad[0.01]$ & $1015 \quad(1015.75)[0]$ & 1100 \\
\hline$>45$ nonvaccinated & $3(3.75)[0.15]$ & $46 \quad(45.25)[0.01]$ & 49 \\
\hline Marginal Column Totals & 88 & 1061 & 1149 (Grand Total) \\
\hline \multicolumn{4}{|c|}{ The chi-square statistic is 0.1708 . The $p$-value is .679375 . Not significant at $p<.05$. } \\
\hline \multicolumn{4}{|c|}{ Table 4: Age related difference in vaccination vs positivity rate } \\
\hline
\end{tabular}

\begin{tabular}{|l|l|l|l|}
\hline & single dose & both doses & Marginal Row Totals \\
\hline Below 45 & $1171 \quad(1126.78)[1.74]$ & $1681 \quad(1725.22)[1.13]$ & 2852 \\
\hline Over 45 & $388(432.22)[4.52]$ & $706(661.78)[2.95]$ & 1094 \\
\hline Marginal Column Totals & 1559 & 2387 & 3946 (Grand Total) \\
\hline \multicolumn{2}{|r|}{ The chi-square statistic is 10.3484. The $p$-value is .001296. Significant at $p<.05}$. \\
\hline Table 5: Age related difference in incomplete(one) or completed (two doses) vaccination \\
\hline
\end{tabular}


medRxiv preprint doi: https://doi.org/10.1101/2021.05.28.21257967; this version posted June 3, 2021. The copyright holder for this preprint (which was not certified by peer review) is the author/funder, who has granted medRxiv a license to display the preprint in perpetuity. It is made available under a CC-BY-NC-ND 4.0 International license .

11

\begin{tabular}{|c|c|c|c|}
\hline All Ages & Covid +ve & Covid-ve & Marginal Row Totals \\
\hline Dose 1 & $128(143.81)$ [1.74] & $1431(1415.19)[0.18]$ & 1559 \\
\hline Dose 2 & $\begin{array}{llll}236 & (220.19) & {[1.14]}\end{array}$ & $2151 \quad(2166.81) \quad[0.12]$ & 2387 \\
\hline Marginal Column Totals & 364 & 3582 & 3946 (Grand Total) \\
\hline \multicolumn{4}{|c|}{ The chi-square statistic is 3.1654. The $p$-value is .075212. Not significant at $p<.05$. } \\
\hline Below 45 & Covid +ve & Covid-ve & Marginal Row Totals \\
\hline Dose 1 & $99 \quad(114.55)[2.11]$ & $1072(1056.45)[0.23]$ & 1171 \\
\hline Dose 2 & $180(164.45) \quad[1.47]$ & $1501(1516.55) \quad[0.16]$ & 1681 \\
\hline Marginal Column Totals & 279 & 2573 & 2852 (Grand Total) \\
\hline \multicolumn{4}{|c|}{ The chi-square statistic with Yates correction is 3.7205. The $p$-value is .053748 . Not significant at $p<.05$. } \\
\hline Above 45 & Covid +ve & Covid-ve & Marginal Row Totals \\
\hline Dose 1 & $29(30.15)[0.04]$ & $359(357.85) \quad[0]$ & 388 \\
\hline Dose 2 & $56 \quad(54.85)[0.02]$ & $650(651.15) \quad[0]$ & 706 \\
\hline Marginal Column Totals & 85 & 1009 & 1094 (Grand Total) \\
\hline \multicolumn{4}{|c|}{ The chi-square statistic is 0.0732 . The $p$-value is .786696. Not significant at $p<.05$. } \\
\hline \multicolumn{4}{|c|}{ Table 6: Single dose vs Two doses and positivity rate } \\
\hline
\end{tabular}

\begin{tabular}{|c|c|c|c|}
\hline & Mild & Moderate/Severe & Marginal Row Totals \\
\hline vaccinated +ve & $\begin{array}{llll}286 & (284.05) & {[0.01]}\end{array}$ & $\begin{array}{lll}62 & (63.95) & {[0.06]}\end{array}$ & 348 \\
\hline nonvaccinated +ve & $\begin{array}{lll}56 & (57.95) & {[0.07]}\end{array}$ & $15 \quad(13.05)[0.29]$ & 71 \\
\hline Marginal Column Totals & 342 & 77 & 419 (Grand Total) \\
\hline \multicolumn{4}{|c|}{ The chi-square statistic is 0.4309 . The $p$-value is .511553. Not significant at $p<.05$. } \\
\hline & Mild & Moderate/Severe & Marginal Row Totals \\
\hline Dose 1 & $102(105.2)[0.1]$ & $26 \quad(22.8) \quad[0.45]$ & 128 \\
\hline Dose 2 & $184(180.8)$ [0.06] & $\begin{array}{lll}36 & (39.2) & {[0.26]}\end{array}$ & 220 \\
\hline Marginal Column Totals & 286 & 62 & 348 (Grand Total) \\
\hline \multicolumn{4}{|c|}{ The chi-square statistic is 0.8618 . The $p$-value is .35324 . Not significant at $p<.05$. } \\
\hline
\end{tabular}

\begin{tabular}{|c|c|c|c|}
\hline & Covid +ve & Covid-ve & Marginal Row Totals \\
\hline without comorbidities & $370(358.38)[0.38]$ & $3273(3284.62)[0.04]$ & 3643 \\
\hline with comorbidities & $72(83.62)[1.61]$ & $778(766.38)[0.18]$ & 850 \\
\hline Marginal Column Totals & $442-3$ & 4051 & 4493 (Grand Total) \\
\hline \multicolumn{4}{|c|}{ The chi-square statistic is 2.2084 . The $p$-value is .137259 . Not significant at $p<.05$. } \\
\hline & Covid +ve & Covid-ve & Marginal Row Totals \\
\hline without comorbidities+vaccinated & $303 \quad(293.07) \quad[0.34]$ & $2887(2896.93)[0.03]$ & 3190 \\
\hline with comorbidities+vaccinated & $61(70.93)[1.39]$ & $711(701.07)[0.14]$ & 772 \\
\hline Marginal Column Totals & 364 & 3598 & 3962 (Grand Total) \\
\hline \multicolumn{4}{|c|}{ The chi-square statistic is 1.8998 . The $\mathrm{p}$-value is .168103 . Not significant at $\mathrm{p}<.05$. } \\
\hline & Covid +ve & Covid-ve & Marginal Row Totals \\
\hline with comorbidities+vaccinated & $\begin{array}{llll}61 & (65.39) & {[0.3]}\end{array}$ & $\begin{array}{lll}711 & (706.61) & {[0.03]}\end{array}$ & 772 \\
\hline with comorbidities+nonvaccinated & $\begin{array}{lll}11 & (6.61) & {[2.92]}\end{array}$ & $\begin{array}{lll}67 & (71.39) & {[0.27]}\end{array}$ & 78 \\
\hline Marginal Column Totals & 72 & 778 & 850 (Grand Total) \\
\hline
\end{tabular}


medRxiv preprint doi: https://doi.org/10.1101/2021.05.28.21257967; this version posted June 3, 2021. The copyright holder for this preprint (which was not certified by peer review) is the author/funder, who has granted medRxiv a license to display the preprint in perpetuity.

It is made available under a CC-BY-NC-ND 4.0 International license .

12

\begin{tabular}{|l|l|l|l|}
\hline & Covid +ve & Covid-ve & Marginal Row Totals \\
\hline Vaccinated Diabetics & $19(20.87)[0.17]$ & $239(237.13)[0.01]$ & 258 \\
\hline Nonvaccinated Diabetics & $3(1.13)[3.08]$ & $11(12.87)[0.27]$ & 14 \\
\hline Marginal Column Totals & 22 & 250 & $272 \quad$ (Grand Total) \\
\hline \multicolumn{2}{|c|}{ The chi-square statistic is 3.5333. The $p$-value is .060146. Not significant at $p<.05}$. \\
\hline Table 9: Vaccination vs positivity in respondents with diabetes \\
\hline
\end{tabular}

\begin{tabular}{|l|l|l|l|}
\hline & Covid +ve & Covid-ve & Marginal Row Totals \\
\hline Covaxin & $25(27.47)[0.22]$ & $274(271.53)[0.02]$ & 299 \\
\hline Covishield & $339(336.53)[0.02]$ & $3324(3326.47)[0]$ & 3663 \\
\hline Marginal Column Totals & 364 & 3598 & $3962 \quad$ (Grand Total) \\
\hline \multicolumn{2}{|r|}{ The chi-square statistic is 0.2645. The $p$-value is .607033. Not significant at $p<.05}$. \\
\hline \multicolumn{2}{|r|}{ Table 10: Effectivity of Covaxin vs Covishield in preventing infection } \\
\hline
\end{tabular}


medRxiv preprint doi: https://doi.org/10.1101/2021.05.28.21257967; this version posted June 3, 2021. The copyright holder for this preprint (which was not certified by peer review) is the author/funder, who has granted medRxiv a license to display the preprint in perpetuity. It is made available under a CC-BY-NC-ND 4.0 International license .

13

\section{Questionnaire}

* Required

1. In which State/UT do you practice? *

2. $\quad$ Age *

3. Sex

$$
\begin{array}{llll}
\text { O25-35 } & \text { O35-45 } & \bigcirc 45-55 & \bigcirc 55 \text { and above } \\
& \text { O Male } & \text { OFemale } & \begin{array}{c}
\text { P Prefer not to } \\
\text { say }
\end{array}
\end{array}
$$

4. Do you suffer from any comorbidities which may make you susceptible to Covid-19?*

5. If yes, mention the comorbidities here*

6. Have you been vaccinated against Covid-19?*
OYes

Covisheild
OYes $\quad$ No

7. If Yes, which vaccine did you received?*

OYes

No doses before 31 st March 2021?*

9. Were you seeing patients for more than 20 days OYes $\quad$ No from 1st March 2021 till date?*

10. Have you tested positive (RT-PCR confirmed) with<smiles>[O][Mg]O</smiles>
Covid-19 during the first wave in $2020 ?^{*}$

11. Have you tested positive (RT-PCR confirmed) with OYes Covid-19 during the ongoing second wave?*

12. How would you classify your symptoms?

13. How long did your symptoms last?

14. Did you require respiratory support?

$\begin{array}{ccc}\text { O Mild } & \text { O Moderate } & \bigcirc \text { Severe } \\ \begin{array}{c}\text { 1 week } \\ \text { or less }\end{array} & \bigcirc 1-2 \text { weeks } & \begin{array}{c}\text { More than } 2 \\ \text { weeks }\end{array}\end{array}$
required to fill the rest of the form) questions) No (skip the Covaxin 
medRxiv preprint doi: https://doi.org/10.1101/2021.05.28.21257967; this version posted June 3, 2021. The copyright holder for this preprint (which was not certified by peer review) is the author/funder, who has granted medRxiv a license to display the preprint in perpetuity. It is made available under a CC-BY-NC-ND 4.0 International license.

14

15. Do you continue to have long-term effects of

OBreathlessness $\bigcirc$ Fatigue $\bigcirc$ Body Ache $\quad$ Other Covid-19? 